\title{
Efektivitas Getah Pohon Jarak Cina Terhadap Perkembangan Kolonisasi Bakteri Luka Insisi Pada Hewan Coba Mus Musculus Strain Balb/C
}

\author{
Suyatno Hadi Saputro ${ }^{1}$, Nugroho Ari Wibowo ${ }^{2}$ \\ ${ }^{1,2}$ Program Studi S1 Keperawatan Fakultas Ilmu Kesehatan Universitas Muhammadiyah Surabaya
}

\section{INFORMASI}

Korespondensi: coolchass87@gmail.com

Keywords:

Disaster, Incision Wound, Chinese Jatropha Tree Gum, Bioplacenton

\section{ABSTRACT}

Geographical, hydrological and sociological conditions support Indonesia as a market of disaster. WHO (2012) explained that open wounds are very at risk of being infected with bacteria in disaster areas, especially with tetanus bacteria. As many as 90\% of all cases of death due to infected wounds (Peden et al, 2008). To overcome this problem the need for wound care using local wisdom local therapy such as Chinese jatroph a tree sap. The purpose of this study was to determine the effectiveness of Chinese jatropha sap on the development of incision wound bacteria in experimental animals Mus musculus Strain Balb / c

The design of this study used a true experiment post only control group design by administering Chinese jatropha tree sap to male mice (bal mus / musculus) strains aged 2 to 2.5 months and weighing 20-30 grams with a total of 30 mice. Mice made incision wounds and observed the number of colonies in the inflammatory and proliferation phases of Chinese jatropha sap and compared with bioplacentons The results of the study in the treatment group were 410 bacteria on average while the control group were 585 bacteria in the inflammatory phase. Furthermore, in the proliferation phase the treatment group averaged 39 bacteria while in the control group there were an average of 79 bacteria. Independent $t$-test results in the inflammatory phase showed that $p=0.042<\alpha=0.05$ Furthermore, in the proliferation phase $p=$ $0.041<\alpha=0.05$, in both phases there was an effect of giving Chinese jatropha tree sap to the amount of bacterial colonization in animals try Mus musculus Strains Balb / c. Chinese jatropha tree sap contains alkaloids, saponins, flavonoids, tannins, and anti-microbial $\beta$-lactams so as to stop the development of bacterial colonies in wounds. It is hoped that the Chinese jatropha sap can be an alternative in the initial treatment of open wounds and incisions in the limitations of medicine when a disaster occurs. 


\section{PENDAHULUAN}

Menurut laporan Annual Disaster Statistical Review (ADSR,2014), Indonesia merupakan salah satu dari lima negara yang paling sering terkena bencana alam. Bencana alam yang terjadi di Indonesia sering sekali menimbulkan kerugian material maupun immaterial, tidak jarang pula menimbulkan korban jiwa yang banyak. BNPB (2012) menyatakan korban meninggal akibat bencana dari tahun 1815-2011 mengalami peningkatan signifikan.

Indonesia sebenarnya mampunyai sistem tanggap darurat terpadu guna menghadapi bencana, dengan harapan mampu mengurangi jumlah korban jiwa. Namun system tersebut dirasa mempunyai kekurangan saat terjadi bencana, dimana yang paling sering adalah terhambatnya distribusi logistik dan obatobatan didaerah bencana (Gustriani, 2010). Akibatnya banyak korban terluka kekurangan obat-obatan saat dibutuhkan. Hal tersebut dipertegas oleh pernyataan Depkes (2011) yang menjelaskan bahwa upaya perbaikan kesehatan didaerah bencana seringkali terhambat dengan terbatasnya logistic beserta obat-obatan. Sehingga penanganan korban bencana seringkali tidak maksimal.

Salah satu kejadian yang dapat menyebabkan kematian pada korban bencana adalah terkontaminasinya luka terbuka. Pada saat terjadi luka, fungsi kulit sebagai barrier akan menghilang dan berakibat pada masuknya mikro organisme patogan kedalam tubuh dan menyebabkan infeksi baik secara lokal maupun sistemik. Depkes (2011) melaporkan luka terbuka merupakan kasus yang sering muncul didaerah bencana. WHO (2012) memaparkan, luka terbuka sangat beresiko terinfeksi bakteri didaerah bencana, terutama dengan bakteri tetanus. Sebanyak 90\% dari semua kasus kematian karena luka terinfeksi.

Untuk mengatasi masalah tersebut dibutuhkan upaya-upaya pemanfaatan yang dimiliki daerah yang terpapar. Pemanfaatan potensi daerah ini dapat meningkatkan derajat kesehatan masyarakat didaerah berdampak (Wibowo, N. A.,2017). Penatalaksanaan rawat luka dengan kearifan local setempat. Metode penggunaan kearifan lokal dengan menggunakan getah pohon jarak cina sejalan dengan program yang digagas oleh BNPB. BNPB dalam rencana strategisnya (2012) menjelaskan upaya penanggulangan bencana tidak bisa bergantung pada pemerintah saja perlu peran aktif masyarakat dalam menghadapi setiap fase bencana. Getah pohon jarak cina dikenal secara turun-temurun menyembuh- kan luka terbuka. Jarak cina diyakini mempunyai kandungan fitokimia yang dapat mempercepat penyembuhan luka. (Murray, Hinkle, \& Yun, 2008). Berdasarkan uraian diatas maka peneliti ingin mengetahui adakah efektivitas pemberian getah pohon jarak cina terhadap kolonisasi bakteri luka insisi pada hewan coba mus musculus strains balb/c?

\section{METODE}

Penelitian ini merupakan penelitian true eksperimental dengan menggunakan metode post test only controlled grup design dengan hewan coba mencit Strains Balb/c sebagai obyek penelitian. Penelitian ini menggunakan hewan coba mencit dengan pertimbangan bahwa mencit mempunyai hematologis yang mirip dengan manusia, relatif tidak membahayakan ketika diberi perlakuan, dan tahan terhadap infeksi. Jumlah sampel pada penelitian ini sebanyak 30 ekor mencit yang dibagi menjadi 2 kelompok. Teknik sampling dalam penelitian ini menggunakan probability sampling jenis simple random sampling dengan tiap-tiap subyek dalam populasi memiliki kesempatan untuk terpilih dan tidak terpilih sebagai sampel dan pemilihan sampel tersebut dilakukan secara random atau acak.

\section{PROSEDUR}

Pengumpulan data pada penelitian ini menggunakan lembar observasi sebagai lembar dokumentasi. Sementara untuk mengukur proses penyembuhan luka Insisi disamping mengobservasi fase-fase penyembuhan luka, juga menghitung jumlah kolonisasi bakteri pada setiap fase. Kriteria penyembuhan luka insisi yakni terdapat progress penutupan luka dari awal dibuatnya luka hingga luka tertutup. Dan akan dibandingkan antara kelompok intervensi dengan kelompok kontrol.

Tahap awal penelitian dilakukan dengan menetapkan subyek penelitian yang sesuai dengan persyaratan sampel yang sudah ditentukan. Kemudian dilakukan pengambilan sampel dengan cara random yang kemudian sampel yang didapatkan dibagi menjadi 2 kelompok. Tiap-tiap kelompok menggunakan kandang yang berbeda, kemudian dilakukan pembuatan luka insisi. Setelah luka terbentuk, kelompok intervensi diberi jarak cina, sedangkan kelompok kontrol menggunakan bioplacentone. Pada masing-masing luka akan akan diobservasi sesuai dengan fase-fase penyembuhan luka dan menggunakan kultur bakteri pada sampel luka tiap 
masing-masing keompok untuk hitung populasi bakteri pada masing-masing kelompok serta didokumentasikan dalam lembar observasi.

\section{HASIL}

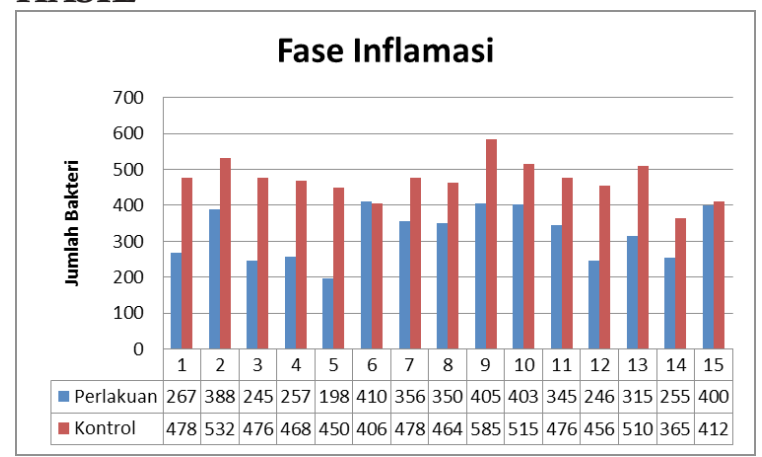

Jumlah kolonisasi terbanyak pada kelompok kontrol dengan menggunakan bioplacenton sejumlah 585 bakteri. Sedangkan pada kelompok perlakuan dengan menggunakan getah pohon jarak cina sejumlah 410 bakteri.

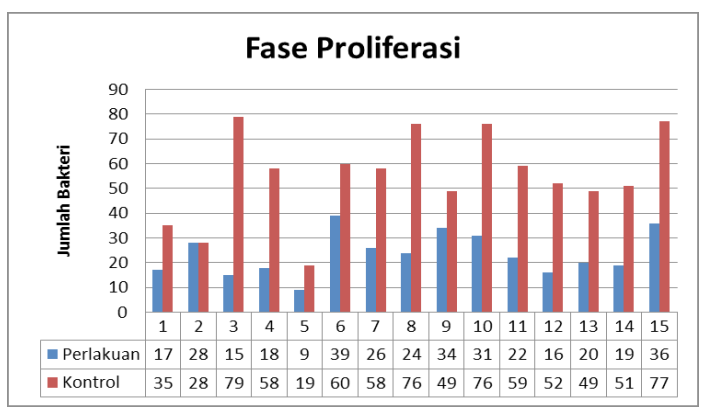

Jumlah kolonisasi bakteri terbanyak terdapat pada kelompok kontrol dengan menggunakan bioplacenton sejumlah 79 bakteri. Sedangkan pada kelompok perlakuan dengan menggunakan getah pohon jarak cina sejumlah 39 bakteri.

\section{Hasil analisis uji statistik}

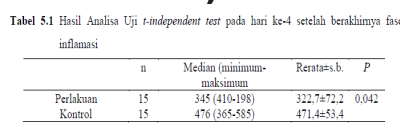

Uji $t$-independent test pada tabel diatas menunjukkan bahwa $\mathrm{p}=0,042<\alpha=0,05$ maka ada pengaruh pemberian getah pohon jarak cina terhadap jumlah kolonisasi bakteri pada hewan coba Mus musculus Strains Balb/c pada hari ke-4 setelah berakhir fase inflamasi.

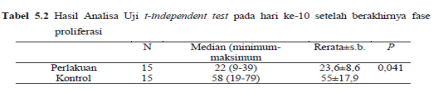

Uji t-independent test pada tabel diatas menunjukkan bahwa $\mathrm{p}=0,041<\alpha=0,05$ maka ada pengaruh pemberian getah pohon jarak cina terhadap jumlah kolo- nisasi bakteri pada hewan coba Mus musculus Strains Balb/c pada hari ke-10 setelah berakhirnya fase proliferasi.

\section{PEMBAHASAN}

Reaksi inflamasi adalah respon fisiologis normal tubuh dalam mengatasi luka. Fase inflamasi bertujuan untuk membunuh bakteri yang terkontaminasi luka (Leong, 2012). Fase inflamasi dimulai setelah beberapa me nit cidera dan akan berlangsung selama sekitar 4-6 hari (Perry\&Potter, 2006). Inflamasi ditandai oleh rubor (kemerahan), tumor (pembengkakan), calor (hangat), dan dolor (nyeri).

Pada kelompok perlakuan getah pohon jarak cina rata -rata banyaknya jumlah kolonisasi bakteri pada hari pertama yaitu 832 bakteri dan menurun pada hari ke-4 setelah berakhirnya fase inflamasi rata-rata sebanyak 323 bakteri. Hal ini disebabkan karena pada kelompok perlakuan getah pohon jarak cina mengandung senyawa tanin, flavonoid, saponin, dan alkaloid yang dapat membantu dalam proses penyembuhan luka. Selain itu getah pohon jarak cina memiliki aktivitas antimikroba yang bermanfaat sebagai pembunuh mikroorganisme inefektif atau mencegah terjadinya infeksi yang sering terjadi pada luka terbuka. Sebagian besar infeksi disebabkan oleh bakteri, jamur, virus, dan parasit. Bakteri yang masuk ke dalam tubuh melalui luka insisi tersebut dapat menyebabkan infeksi yaitu Staphyococcus aureus dan Escherchia coli (Brooks et al., 2007). Selain itu senyawa saponin dapat bekerja sebagai antiseptik yang berfungsi untuk menghambat pertumbuhan bakteri (Wibowo, 2017)

Sedangkan pada kelompok perlakuan kontrol dengan menggunakan obat topical bioplacenton rata-rata kolonisasi bakteri hari ke- 4 setelah berakhirnya fase inflamasi rata-rata sebanyak 471 bakteri. Hal ini dikarenakan kandungan dalam bioplacenton yaitu neomysin sulfat $0,5 \%$ yang berperan penting sebagai antibiotik dan ekstrak plasenta sebagai simulator dalam regenerasi sel.

Selanjutnya, Berdasarkan gambar diatas didapatkan bahwa jumlah kolonisasi bakteri terbanyak terdapat pada kelompok kontrol dengan menggunakan bioplacen ton dengan jumlah kolonisasi sebanyak 79 bakteri pada hari ke-10 berakhirnya fase proliferasi sedangkan pada kelompok perlakuan dengan menggunakan getah pohon jarak cina hanya sebanyak 39 bakteri. Selanjutnya jumlah kolonisasi paling sedikit pada hari ke -10 berakhirnya fase prolifera- 
si terdapat pada kelompok perlakuan dengan menggunakan getah pohon jarak cina yaitu sebanyak 9 bakteri dan kelompok kontrol dengan menggunakan bioplacenton sebanyak 19 bakteri.

Pada fase proliferasi yang berlangsung hingga hitungan minggu atau 3-14 hari. Pembentukan granulasi terjadi pada hari ke-2 sampai ke-5 setelah luka, dibentuk oleh fibroblast yang mengalami proliferasi dan maturasi. Fibroblast akan bekerja menghasilkan ECM untuk mengisi celah yang terjadi akibat luka dan sebagai perantara migrasi keratinosit. Matriks ini akan tampak jelas pada luka. Makrofag akan menghasilkan growth factor yang merangsang fibroblast berproliferasi. Makrofag juga akan merangsang sel endotel untuk membentuk pembuluh darah baru (Gurtner, 2007).

Pembentukan pembuluh darah baru atau angiogenesis dimulai pada akhir fase inflamasi. Angiogenesis diperlukan untuk mengatur vaskulerisasi yang rusak akibat luka dan distimulasi kondisi laktat yang tinggi, kadar $\mathrm{pH}$ yang asam dan penurunan tekanan oksigen dijaringan (Leong, 2012). Vascular endhotelial growth factor (VEGF) sebagai faktor angiogenik yang poten dihasilkan oleh keratinosit, makrofag dan fibroblast selama proses penyembuhan. fibroblast mengeluarkan matriks mettaloproteinase (MMP) untuk memecah matriks yang menghalangi migrasi. Fungsi utama dari fibroblast adalah sintesis kolagen.

Pada kelompok perlakuan getah pohon jarak cina rata-rata 24 bakteri dan pada kelompok bioplacenton rata-rata 55. Hal ini terjadi karena getah pohon jarak cina mempunyai kandungan flavonoid, triterpenoid, tanin, dan saponin. Flavonoid diketahui memiliki antiskorbut yang berperan dalam melindungi asam askorbat dari oksidasi sehingga proses sintesis kolagen dapat berjalan dengan baik. Flavonoid juga dapat bertindak melindungi lipid membran terhadap agen yang merusak (Robinson, 1995). Diduga aksi ini yang menjaga membran sel tidak mudah dirusak bakteri dan tetap berfungsi dengan baik untuk melakukan perbaikan selama proses penyembuhan. Hal ini sejalan dengan penelitian yang dilakukan oleh Wibowo (2017) yang mengatakan bahwa kandungan flavonoid dapat membantu dalam penyembuhan luka karna sifatnya yg antimikroba.

\section{KESIMPULAN}

1. Perkembangan kolonisasi luka insisi pada hewan coba mus musculus strain balb/c pada hari ke-4 setelah berakhirnya fase inflamasi rata-rata sebanyak 323, selanjutnya pada hari ke-10 setelah berakhirnya fase proliferasi sebanyak 24 bakteri

2. Perkembangan kolonisasi luka insisi pada hewan coba mus musculus strain balb/c dengan menggunakan bioplacenton pada hari ke-14 setelah berakhirnya fase inflamasi rata-rata sebanyak 471 bakteri, selanjutnya pada hari ke 10 setelah berakhirnya fase proliferasi sebanyak 55 bakteri

3. Perkembangan kolonisasi luka insisi pada hewan coba mus musculus strain balb/c dengan menggunakan getah pohon jarak cina dan bioplacenton pada fase inflamasi dan fase proliferasi terdapat perbedaan.

\section{DAFTAR PUSTAKA}

Ahern, M., Kovats, R. S., Wilkinson, P., Few, R., \& Matthies, F. (2005). Global Health Impacts Of Floods: Epidemiologic Evidence. Epidemiologic Reviews, 27, 36-46. Doi:10.1093/Epirev/ Mxi004

Benedict, K., \& Park, B. J. (2015). Invasive Fungal Infections After Natural Disasters. Emerging Infectious Disease, 20(3), 349-355.

Bnpb. (2012A). Pedoman Umum Desa/Kelurahan Tangguh Bencana.

Bnpb. (2012B). Buku Saku Tanggap Tangkas Bencana.

Bnpb. (2015). Rencana Nasional Penanggulangan Bencana.

De, A., Morey, P., Jg, S., Bp, M., Angel, D., \& Hospital, C. G. (2008). The Great Debate Over Iodine In Wound Care Continues: A Review Of The Literature. Wound Practice And Research Journal, 16(1).

Depkes. (2001). Pedoman Penanggulangan Masalah Kesehatan Akibat Kedaruratan Kompleks.

Guha-Sapir, D., Hoyois, P., \& Below, R. (2014). Annual Disaster Statistical Review 2014 The Numbers And Trends.

Idep. (2007). Panduan Umum Penanggulangan Bencana Berbasis Masyarakat.

Kemenkes. (2015). Rencana Strategis Kementerian Kesehatan Tahun 2015-2019.

Lemonick, D. M. (2011). Epidemics After Natural Disasters. American Journal Od Clinical 
Medicine, 8(3), 144-152.

Lockwood, J. S., \& White, W. L. (2011). The Use Of Penicillin In Surgical Infections. Annals Of Surgery, 311-344.

Murray, C. K., Hinkle, M. K., \& Yun, H. C. (2008). History Of Infections Associated With Combat-Related Injuries. The Journal Of Trauma, 64(3 Suppl), S221-31. Doi:10.1097/ Ta.0B013e318163c40b

Pandey, B., \& Okazaki, K. (2011). Community Based Disaster Management: Empowering Communities To Cope With Disaster Risks. Disaster Management.

Rodriguez, M. (2010). Bite Wound Infections. Emerging Infectious Disease, 10(1).

Stashak, T. (2010). Management Practices That Influence Wound Infection And Healing. Wound Care And Scar Management Journal.

Victoria, L. P. (2000). Community Based Disaster Management In The Philippines: Making A Diference In People's Lives. Disaster Preparedness, $0-8$.

Who. (2014). Prevention And Management Of Wound Infection.

Wibowo, N.a., (2017). Pengaruh Getah Tunas Pisang (Musa Paradisiaca Var. Sapientum) Terhadap Perkembangan Koloni Luka Bakar Grade Ii Pada Mencit (Mus Musculus). Jurnal Keperawatan Muhammadiyah 2 (2) Vol. 2017.

Wibowo, N.a., (2017). Pengaruh Olesan Minyak Cengkeh (Syzygium Aromaticum L). Terhadap Proses Penyembuhan Luka Insisi Pada Hewan Coba Mencit (Mus Musculus). Jurnal Keperawatan Muhammadiyah 2 (2) Vol. 2017.

Wibowo, N.a., 2017. Peran Postaga Dalam Pemberdayaan Kesiapsiagaan Masyarakat Dalpenang Sampang. Aksiologiya: Jurnal Pengabdian Kepada Masyarakat. Vol 1, No.2. Hal 119-125

Wuthisuthimethawee, P., Lindquist, S. J., Watters, D., \& Gruen, R. L. (2014). Wound Management In Disaster Settings. World Journal Of Surgery. Doi:10.1007/S00268-014-2663-3

Zourgui, L. (2008). Community-Based Disaster Management. Flash Flood Early Warning System Reference Guide (Pp. 1-16) 